\title{
ZASTUPLJENOST POTEŠKOĆA I ZADOVOLJSTVO RAZLIČITIM ASPEKTIMA ŽIVOTA KOD STUDENATA ZDRAVSTVENIH STUDIJA
}

\author{
Olivera Petrak \\ Katedra za zdravstvenu psihologiju Zdravstvenog veleučilišta \\ Mlinarska 38, 10000 Zagreb \\ olivera.petrak@zvu.hr \\ Melita Rukavina \\ Katedra za zdravstvenu psihologiju Zdravstvenog veleučilišta \\ Mlinarska 38, 10000 Zagreb \\ melita.rukavina@zvu.hr \\ Iva Takšić \\ Katedra za zdravstvenu psihologiju Zdravstvenog veleučilišta \\ Mlinarska 38, 10000 Zagreb \\ iva.taksic@zvu.hr
}

\begin{abstract}
Sažetak
Istraživanja psihološke prilagodbe studenata pokazuju da je to populacija u kojoj se često pojavljuju emocionalni, motivacijski i socijalni problemi koji su usko povezani s problemima učenja, izborom studija i akademskim neuspjehom. Zanimalo nas je s kojim problemima se susreću studenti zdravstvenih studija na jednom od većih veleučilišta u Hrvatskoj, smještenom u Zagrebu. Proveli smo ispitivanje na 423 studenta primijenivši anketu koju nam je ustupilo Savjetovalište za studente Filozofskog fakulteta u Zagrebu, kojom se ispituju poteškoće studenata, zadovoljstvo različitim aspektima života, kao i spremnost da se obrate za pomoć. Prosječna dob sudionika je 20,9 godina i prevladavaju studentice $(79 \%)$.

U slučaju poteškoća, $51,5 \%$ studenata potražilo bi besplatnu psihološku pomoć, pri čemu značajno više studenata treće godine. Studenti u prosjeku navode 14 poteškoća, a najčešće su nervoza ili napetost, nesigurnost glede buduće karijere, neracionalno korištenje vremena, financijski problemi, te promjene u navikama hranjenja. Studenti druge godine navode značajno više poteškoća u odnosu na ostale. Također, studentice navode značajno veći broj poteškoća od studenata, a ujedno su i značajno manje zadovoljne svojim kompetencijama, te tjelesnim izgledom.
\end{abstract}

Ključne riječi: studenti, psihološke poteškoće, psihološka pomoć, zadovoljstvo životom. 


\section{UVOD}

U Hrvatskoj se u proteklih nekoliko godina može opaziti kontinuirani rast upisanih studenata na visoka učilišta, te je tako u 2016./2017. bilo 1,7\% više upisanih studenata nego prethodne akademske godine (prema Državnom zavodu za statistiku). Unatoč porastu broja diplomiranih studenata, zabrinjavajuća je činjenica da se broj ukupno diplomiranih studenata kreće između 25 i 35\% od ukupnog broja upisanih, te da manje od $15 \%$ uspijeva diplomirati u redovitom roku (Jokić-Begić, Lugomer-Armano i Vizek Vidović, 2009). Uzroci ovako slaboj učinkovitosti studiranja ne mogu se pripisati samo nedovoljnoj osposobljenosti završenih srednjoškolaca, već treba uzeti u obzir i druge faktore kao što su raznolikost njihovih akademskih i kognitivnih sposobnosti, te socijalnih, obrazovnih i motivacijskih obilježja (JokićBegić i sur., 2009).

Dolazak na studij je značajan, ali i stresan životni događaj jer pred mlade ljude postavlja brojne nove zahtjeve i traži preuzimanje niza novih uloga, te njihovo usklađivanje s postojećima. Dok će kod nekih takva vrsta stresa povećati motivaciju i ustrajnost u studiranju, kod drugih će imati negativne posljedice za akademski uspjeh. Intenzivne društvene promjene, kao i promjene u suvremenom visokom obrazovanju postavljaju pred studente sve veće zahtjeve i povećavaju nesigurnost mladih ljudi.

Istraživanja psihološke prilagodbe studenata pokazuju da je to populacija u kojoj se često pojavljuju emocionalni, motivacijski i socijalni problemi koji su usko povezani s problemima učenja, izborom studija i akademskim neuspjehom (Bezinović, Pokrajac-Bulian, Smojver-Ažić i Živčić-Bećirević, 1998). Istraživanje na studentima s američkih sveučilišta utvrdilo je da su poteškoće sa spavanjem, stres, anksioznost i depresija četiri glavne prepreke akademskom uspjehu (Douce i Keeling, 2014).

Činitelji koji su uključeni u odluku o prekidu studija obično nisu "katastrofalni”, već su to tipični problemi rane odrasle dobi (Berk, 2008). Većina studenata se tijekom studija suočava s blažim i prolaznim smetnjama u obliku napetosti, tjeskobe i nesigurnosti. Slična je situacija i u Hrvatskoj: na Sveučilištu u Rijeci najčešći problemi su tjeskoba vezana uz studij, nezadovoljstvo studijem i nedostatak motivacije, problemi u socijalnim odnosima, napetost i opće nezadovoljstvo, nezadovoljstvo sobom i vlastitim izgledom, osjećaj neprimjerenosti, te ljubavni i seksualni problemi (Bezinović i sur., 1998). Slični problemi uzrokom su javljanja u Studenski savjetovališni centar (Živčić-Bećirević, Smojver-Ažić, Kukić i Jasprica, 2007). Istraživanje na studentima 19 fakulteta Sveučilišta u Zagrebu pokazalo je da studenti najčešće navode emocionalne smetnje, poteškoće vezano uz studij, smetnje ponašanja/agresija, probleme $u$ odnosima, te probleme u prilagodbi, što je u skladu $\mathrm{s}$ ranije navedenim rezultatima. Studenti su u prosjeku najmanje zadovoljni uspjehom na studiju i vještinama učenja, dok je zadovoljstvo ostalim aspektima života relativno visoko (Jokić-Begić i sur., 2009). 
Cvitan, Doolan, Farnell i Matković (2011) utvrdili su da 15\% studenata u Hrvatskoj ima tjelesne ili psihičke teškoće koje ih ometaju za vrijeme studija, a većina ih smatra kako se na njihovom studiju o tome ne vodi računa (68\% studenata). Pojavnost depresije, anksioznosti i fobija kod studenata je 2,6 puta veća nego u općoj populaciji (Lenz, Vinković i Degmečić, 2016). Zabrinjavajuće je da posljednjih godina raste broj studenata s ozbiljnim psihološkim problemima kao što su uzimanje droga, obiteljsko nasilje, spolno zlostavljanje, samodestruktivne misli i sl. (Gallagher, 2014).

Studenti prve godine najrizičnija su skupina za odustajanje od studija, dok su teškoće s mentalnim zdravljem koje se pojavljuju na višim godinama studija obično ozbiljnije prirode (Jokić-Begić i sur., 2009). Većina istraživanja ne nalazi rodne razlike u prilagodbi, a tamo gdje ih i ima, one su male i upućuju na nešto bolju emocionalnu prilagodbu mladića, odnosnu bolju akademsku i socijalnu prilagodbu djevojaka (Živčić-Bećirević i sur., 2007; Zascavage, Winterman, Buot, Wies i Lyzinski, 2012). Iz ovoga možemo zaključiti kako je važno studentima ponuditi pomoć. Mladi ljudi koji osjećaju da su ušli u fakultetsku zajednicu koja brine o njima kao pojedincima, vjerojatnije će ustrajati u studiju do diplomiranja i imati manje psihičkih poteškoća (Wilson, Mason i Ewing, 1997, prema Kitzrow, 2003). Sve više studenata i traži savjetodavnu pomoć. To može odražavati pozitivnu promjenu u stavovima o tretmanu mentalnih poremećaja i upućivati na veću prihvaćenost takvog oblika podrške od strane novijih generacija (Francis i Horn, 2017). Međutim, još uvijek su zabrinjavajuće razlike u broju studenata kojima je potrebna stručna pomoć i onih koji je zaista i potraže. Tako su Bojanić, Gorski i Razum (2016) utvrdili da $32,8 \%$ studenata Sveučilišta u Zagrebu ima klinički indikativne psihičke smetnje, od kojih je samo 23,6\% potražilo pomoć. Analize učinkovitosti rada studenskih savjetovališta govore u prilog važnosti njihova postojanja u okvirima akademske zajednice jer pokazuju kako većina studenata nakon tretmana postiže u prosjeku bolji akademski uspjeh, izražava nižu anksioznost, nižu depresivnost i bolje opće funkcioniranje (Devi, Devaki, Madhavan i Saikumar, 2013; Jakovčić, Živčić-Bećirević i Birosavljević, 2015).

Bolje poznavanje psiholoških problema studenske populacije može pomoći u razumijevanju akademskog neuspjeha studenata. Poznavanje potreba važno je i radi izrade odgovarajućih strategija i programa za uklanjanje problema s kojima se studenti suočavaju, ali i za njihovu prevenciju, te omogućuje izradu smjernica koje bi kao konačan cilj trebale imati stvaranje boljih uvjeta za kvalitetnije studiranje i brže akademsko napredovanje.

Kako bi stekli što bolji uvid u potrebe veleučilišnih studenata, proveli smo istraživanje s ciljem utvrđivanja dominantnih problema s kojima se studenti suočavaju, te ispitali njihovo zadovoljstvo različitim aspektima života te spremnost da se obrate za pomoć. Osim toga, provjerili smo odnos promatranih varijabli s obzirom na neka sociodemografska obilježja. 


\section{METODA}

\section{Sudionici}

Uzorak je obuhvatio 423 redovna studenta/ice Zdravstvenog veleučilišta (ZVU) u Zagrebu, prosječne dobi 20,9 godina (raspon 18-41 godina), od čega je 78,7\% ženskog spola, a 21,3\% muškog. Najviše je studenata s treće godine studija (175 studenata - 41,6\%), dok je udio studenata s prve i druge godine po $29,2 \%$ (123 studenta). Za 230 (54,8\%) studenata Zagreb je mjesto prebivališta, dok je $190(45,2 \%)$ došlo na studij u Zagreb iz drugih sredina. U braku je 13 studenata $(3,1 \%)$, te ih samo petoro ima djecu $(1,2 \%)$. Troškove studija za 372 studenta financiraju roditelji $(89,9 \%), 23$ studenta $(5,5 \%)$ ima vlastite prihode u obliku osobnog dohotka kao osnovni izvor pokrivanja troškova studiranja, a nešto manji postotak $(4,6 \%$ - 19 sudionika) prima stipendiju. Ostalih sedmoro nisu dali odgovor na to pitanje.

\section{Instrumentarij}

U istraživanju su, uz dopuštenje autorica, korišteni instrumenti koje su za potrebe projekta DUCAS ${ }^{1}$ koristili djelatnici Savjetovališta za studente Filozofskog fakulteta u Zagrebu, Rijeci i Zadru (Jokić-Begić i sur., 2009). Osim demografskih podataka i podataka o studiju, uključene su sljedeće ankete: procjena zadovoljstva različitim aspektima života, vrste emocionalnih i psihičkih poteškoća, spremnost osobe da se obrati za pomoć, te zainteresiranost za savjetovanje.

\section{Procjena zadovoljstva različitim aspektima života}

Aspekti života obuhvaćaju odnose s drugim bitnim ljudima, osobine studenata, te uspješnost u studiranju. Studente se pita da procijene koliko su zadovoljni pojedinim aspektom svog života, a ponuđeni odgovori kreću se od 1 - potpuno nezadovoljan/a do 5 - izuzetno zadovoljan/a. Provedena eksploratorna faktorska analiza glavnih komponenti rezultirala je ekstrakcijom tri faktora koji zajedno objašnjavaju 51,57\% varijance. Nakon kosokutne oblimin rotacije prvi faktor obuhvaća četiri čestice koje se odnose na kompetencije (uspjeh u studiju, vještine ophođenja, rješavanje problema i vještine učenja), drugim faktorom zasićene su četiri čestice koje se odnose na prijatelje, roditelje, braću/sestre i druge ljude, dok treći faktor obuhvaća dvije čestice različite po smislu (ljubavna veza i tjelesni izgled), a ni jedna od navedenih čestica nema zasićenje na prvom ili drugom faktoru. Pouz-

1 DUCAS je TEMPUS projekt pod nazivom "Developing university counselling and advisory services", koji se odvijao tijekom 2007./8. godine na Zagrebačkom, Riječkom i Zadarskom sveučilištu. 
danost izražena kao Cronbachov alfa koeficijent za prvi faktor koji ćemo imenovati Kompetencije iznosi 0,645, za Odnose s drugima iznosi 0,60, a za treći faktor samo 0,26 . S obzirom na mali broj čestica po pojedinoj subskali, prve dvije pouzdanosti možemo smatrati zadovoljavajućima. Treći faktor bit će izostavljen iz daljnje obrade podataka zbog njegove strukture i niske pouzdanosti.

\section{Vrste psihičkih poteškoća}

Upitnik se sastoji od 60 opisa psihičkih poteškoća, od vrlo učestalih kao što su napetost, teškoće $s$ učenjem, do težih poteškoća koje mogu upućivati na ozbiljne psihičke poremećaje. Ponuđeni odgovori su dihotomni (da/ne), pa nije opravdano provesti faktorsku analizu koja se temelji na Pearsonovim koeficijentima korelacije jer čestice izražene na nominalnoj mjernoj skali ne zadovoljavaju preduvjete za njezinu primjenu (Harris, 1975; Tabachnick i Fidell, 2007). Pouzdanost cijele skale iznosi KR-20 =0,88.

Spremnost osobe da se obrati za pomoć

Ova varijabla mjeri se jednim pitanjem na koje su mogući odgovori $d a$, ne znam ine.

\section{Zainteresiranost za vrstu savjetovanja}

Studente smo pitali za koje su oblike pomoći najviše zainteresirani, a ponuđeno im je individualno i grupno savjetovanje, te radionice, pri čemu su mogli odabrati više odgovora.

\section{Postupak}

Istraživanje je odobreno od strane etičkog povjerenstva ZVU-a. Ispitivanje je bilo anonimno, uz dobrovoljno sudjelovanje studenata, te provedeno grupno u manjim skupinama.

\section{REZULTATI}

Prva primijenjena skala odnosila se na zadovoljstvo različitim aspektima života naših studenata. U Tablici 1 prikazani su osnovni parametri deskriptivne statistike za subskale zadovoljstva životom i za pojedine čestice, kako bismo precizno utvrdili kojim aspektima života su studenti najviše, odnosno najmanje zadovoljni.

Studenti su najviše zadovoljni odnosima s roditeljima, te potom ujednačeno braćom/sestrama i prijateljima, a najmanje zadovoljni drugim ljudima, vještinama učenja i ljubavnom vezom. Izrazili smo i ukupne rezultate na subskalama, te prema istima možemo zaključiti kako su studenti prilično zadovoljni svojim odnosima s drugima $(\mathrm{M}=4,12 ; \mathrm{SD}=0,52)$, te malo manje zadovoljni svojim kompetencijama $(\mathrm{M}=3,72 ; \mathrm{SD}=0,5)$. 
Tablica 1. Deskriptivna statistika zadovoljstva različitim aspektima života studenata

\begin{tabular}{lcccc}
\hline Čestice & Raspon & D & M & SD \\
\hline Uspjeh u studiju & $1-5$ & 4 & 3,83 & 0,72 \\
Ljubavna veza & $1-5$ & 4 & 3,68 & 1,76 \\
Prijatelji & $1-5$ & 4 & 4,31 & 0,71 \\
Roditelji & $1-5$ & 5 & 4,38 & 0,79 \\
Braća/sestre & $1-5$ & 5 & 4,31 & 0,82 \\
Drugi ljudi & $1-5$ & 3 & 3,43 & 0,72 \\
Tjelesni izgled & $1-5$ & 4 & 3,73 & 0,74 \\
Vještine ophođenja & $2-5$ & 4 & 3,75 & 0,67 \\
Rješavanje problema & $1-5$ & 4 & 3,76 & 0,97 \\
Vještine učenja & $1-5$ & 4 & 3,53 & 0,81 \\
\hline Subskale & Raspon & $\mathrm{D}$ & $\mathrm{M}$ & $\mathrm{SD}$ \\
\hline Odnosi s drugima & $1,75-5$ & 4 & 4,12 & 0,52 \\
Kompetencije & $1,25-5$ & 4,5 & 3,72 & 0,50 \\
\hline
\end{tabular}

Legenda: D - dominantna vrijednost; $\mathrm{M}$ - aritmetička sredina; SD - standardna devijacija

Iz Tablice 2 vidljivo je kako su studentice značajno manje zadovoljne svojim tjelesnim izgledom od svojih muških kolega, kao i zadovoljstvom u vještinama ophođenja s drugim ljudima, te rješavanjem problema. Promatrano po subskalama, u procjeni zadovoljstva svojim kompetencijama pronašli smo značajnu razliku među spolovima, gdje su studentice značajno manje zadovoljne od svojih muških kolega.

Studenti na višim godina studija zadovoljniji su svojim uspjehom, a Bonferroni post hoc test pokazuje da se sve skupine međusobno značajno razlikuju $(\mathrm{F}=25,82$; $\mathrm{P}=0,000)$. Po zadovoljstvu tjelesnim izgledom studenti treće godine značajno su

Tablica 2. Značajno različiti aspekti zadovoljstva životom studenata s obzirom na spol

\begin{tabular}{|c|c|c|c|c|c|}
\hline Čestice & & M & SD & $\mathrm{t}$ & $\mathrm{p}$ \\
\hline \multirow{2}{*}{ Tjelesni izgled } & Ženski & 3,67 & 0,73 & \multirow{2}{*}{3,18} & \multirow{2}{*}{0,002} \\
\hline & muški & 3,94 & 0,74 & & \\
\hline \multirow{2}{*}{ Vještine ophođenja } & ženski & 3,70 & 0,66 & \multirow{2}{*}{2,67} & \multirow{2}{*}{0,009} \\
\hline & muški & 3,92 & 0,70 & & \\
\hline \multirow{2}{*}{ Rješavanje problema } & ženski & 3,67 & 0,65 & \multirow{2}{*}{4,78} & \multirow{2}{*}{0,000} \\
\hline & muški & 4,10 & 0,68 & & \\
\hline \multirow{2}{*}{ Subskala kompetencije } & Ženski & 3,68 & 0,49 & \multirow{2}{*}{3,39} & \multirow{2}{*}{0,001} \\
\hline & muški & 3,88 & 0,51 & & \\
\hline
\end{tabular}


zadovoljniji od studenata druge godine $(\mathrm{F}=3,69 ; \mathrm{P}=0,03)$. Brucoši su značajno manje zadovoljni svojim vještinama učenja $(\mathrm{F}=8,47 ; \mathrm{P}=0,004)$ u odnosu na studente viših godina. Značajna razlika dobivena je i za subskalu kompetencije $(\mathrm{F}=$ $13,62 ; \mathrm{P}=0,000)$, pri čemu brucoši opet postižu najniži rezultat. Ni za jedan aspekt zadovoljstva životom nije utvrđena značajna interakcija spola i godine studija.

Najviše nas je zanimalo utvrditi psihološke poteškoće s kojima se susreću studenti tijekom studija. U Tablici 3 prikazani su postoci odabranih odgovora, a poteškoće su poredane po učestalosti pojavljivanja.

Tablica 3. Učestalost pojavljivanja poteškoća studenata uz istaknute značajne rodne razlike

\begin{tabular}{|c|c|c|c|c|}
\hline & & & & \\
\hline & Poteškoće & & DA & $\mathrm{NE}$ \\
\hline 1. & Napetost ili nervoza & & 87,2 & 12,8 \\
\hline 2. & Nesigurnost $\mathrm{u}$ vezi s budućom karijerom & & 55,6 & 44,4 \\
\hline 3. & Neracionalno korištenje vremena za učenje i zabavu & & 53,4 & 46,6 \\
\hline 4. & Financijski problemi & & 45,9 & 54,1 \\
\hline 5. & Promjene u navikama u vezi s hranjenjem & & 45,4 & 54,6 \\
\hline 6. & Nezadovoljstvo studijem & & 43,0 & 57,0 \\
\hline 7. & Nedostatak motivacije & & 42,8 & 57,2 \\
\hline 8. & Problemi vezani uz ljubavni život & & 36,9 & 63,1 \\
\hline 9. & Nezadovoljstvo vlastitom tjelesnom težinom & $\check{Z}^{* *}$ & 36,6 & 63,4 \\
\hline 10. & Osjećaj nepovjerenja u druge ljude & & 36,6 & 63,4 \\
\hline 11. & Sumnja u pravilan izbor studija & $\check{Z}^{* *}$ & 36,4 & 63,6 \\
\hline 12. & Osjećaj snažne tjeskobe u vezi s polaganjem ispita & & 36,2 & 63,8 \\
\hline 13. & Osjećaj neefikasnog studiranja & & 32,9 & 67,1 \\
\hline 14. & Obeshrabrenost budućnošću & & 32,9 & 67,1 \\
\hline 15. & Pretjerana samokritičnost & & 31,2 & 68,8 \\
\hline 16. & Strah od neuspjeha u studiju & $\check{Z}^{* *}$ & 31,2 & 68,8 \\
\hline 17. & Problemi sa spavanjem & & 30,3 & 69,7 \\
\hline 18. & Teškoće s učenjem & & 28,6 & 71,4 \\
\hline 19. & Poteškoće u vezi s polaganjem ispita & & 27,2 & 72,8 \\
\hline 20. & Poteškoće u donošenju važnih odluka & & 27,2 & 72,8 \\
\hline 21. & Nedostatak svijesti o vlastitim sposobnostima & & 26,7 & 73,3 \\
\hline 22. & Osjećaj usamljenosti i nedostatak emocionalne podrške & & 26,2 & 73,8 \\
\hline 23. & Nesuglasice i konflikti s roditeljima & & 26,2 & 73,8 \\
\hline 24. & Nezadovoljstvo vlastitim izgledom & $\check{Z}^{* *}$ & 25,5 & 75,5 \\
\hline 25. & Osjećaj nerazumijevanja od okoline & & 24,1 & 75,9 \\
\hline 26. & Zabrinutost time što drugi ljudi misle o meni & & 22,7 & 77,3 \\
\hline 27. & Depresivnost i osjećaj bespomoćnosti & & 22,2 & 77,8 \\
\hline
\end{tabular}




\begin{tabular}{|c|c|c|c|c|}
\hline & & & & \\
\hline & Poteškoće & & DA & $\mathrm{NE}$ \\
\hline 28. & Nezadovoljstvo samim sobom & $\check{Z}^{* *}$ & 22,2 & 77,8 \\
\hline 29. & Problemi u odnosima s prijateljima & & 22,0 & 78,0 \\
\hline 30. & Tuga i bol nakon prekida veze & & 21,5 & 78,5 \\
\hline 31. & Zdravstveni problemi & $\check{Z}^{*}$ & 20,5 & 69,5 \\
\hline 32. & Opća tjeskoba & & 20,1 & 79,9 \\
\hline 33. & Problemi s cimerom/cimericom & & 19,9 & 81,1 \\
\hline 34. & Pritisci i visoka očekivanja obitelji & & 19,9 & 80,1 \\
\hline 35. & Loša komunikacija s profesorima & & 19,9 & 80,1 \\
\hline 36. & Problemi suočavanja s gubitkom bliske osobe & & 18,9 & 81,1 \\
\hline 37. & Poteškoće s prilagođavanjem režimu studiranja & & 17,3 & 82,7 \\
\hline 38. & Traženje vlastitog identiteta & & 16,5 & 83,5 \\
\hline 39. & Osjećaj manje vrijednosti & $\check{Z}^{*}$ & 16,1 & 83,9 \\
\hline 40. & $\begin{array}{l}\text { Problemi s privremenim smještajem } \\
\text { (dom, podstanarstvo) }\end{array}$ & & 15,4 & 84,6 \\
\hline 41. & Razmišljanja o napuštanju studija & & 14,7 & 85,3 \\
\hline 42. & Povremena agresivna i destruktivna ponašanja & & 12,3 & 87,7 \\
\hline 43. & Omalovažavanje samoga sebe & $\check{Z}^{*}$ & 12,3 & 87,7 \\
\hline 44. & Problemi u intimnoj vezi & & 12,3 & 87,7 \\
\hline 45. & Pretjerano konzumiranje alkohola & $\mathrm{m}^{* *}$ & 11,3 & 88,7 \\
\hline 46. & Poteškoće u prilagodbi mjestu studiranja i okolini & $\check{Z}^{*}$ & 10,9 & 89,1 \\
\hline 47. & Problemi vezani uz seksualni život & & 9,0 & 91,0 \\
\hline 48. & Trajniji osjećaj nezadovoljstva & & 8,7 & 91,3 \\
\hline 49. & Nemogućnost kontrole i lako ulaženje u sukobe & & 8,3 & 91,7 \\
\hline 50. & $\begin{array}{l}\text { Nemogućnost ostvarivanja kontakta s roditeljima i } \\
\text { bliskim osobama }\end{array}$ & & 7,3 & 92,7 \\
\hline 51. & Alkoholizam u obitelji & & 5,4 & 94,6 \\
\hline 52. & Neprihvaćanje od društva & & 4,0 & 96,0 \\
\hline 54. & Problemi stupanja u seksualne odnose & & 3,8 & 96,2 \\
\hline 55. & Uzimanje droge & $\mathrm{m}^{* *}$ & 3,3 & 96,7 \\
\hline 56. & Dodir s kriminalom & $\mathrm{m}^{* *}$ & 2,6 & 97,4 \\
\hline 57. & Uporaba laksativa, povraćanje ili ekstremna dijeta & & 2,1 & 97,9 \\
\hline 58. & Misli o samoozljeđivanju ili samoubojstvu & & 2,1 & 97,9 \\
\hline 59. & Neželjeni seksualni odnosi & & 0,5 & 99,5 \\
\hline 60. & Seksualni napad ili silovanje & & 0,2 & 99,8 \\
\hline
\end{tabular}

Legenda: ž - značajno veći rezultat za studentice; $\mathrm{m}$ - značajno veći rezultat za studente;

* - razlika značajna na razini od 0,$05 ; * *$ - razlika značajna na razini 0,01 
Rezultati u Tablici 3 pokazuju kako se u vrlo visokom postotku pojavljuju napetost ili nervoza, nesigurnost glede buduće karijere, te neracionalno korištenje vremena za učenje i zabavu. Ti se problemi pojavljuju kod više od polovine ispitanih studenata. U znatnom postotku navedeni su i financijski problemi (45,9\%), promjene u navikama u vezi s hranjenjem $(45,4 \%)$ i nedostatak motivacije $(42,8 \%)$. Iako s malom učestalošću, u našem uzorku pojavljuju se oblici ovisničkog ponašanja kao što je pretjerivanje s alkoholom $(\mathrm{N}=48)$, te oblici kriminalnog ponašanja kao što su konzumacija droge $(\mathrm{N}=14)$, dodir s kriminalom $(\mathrm{N}=11)$ te zabrinjavajući problemi kao što su misli o samoozljeđivanju ili samoubojstvu $(\mathrm{N}=9)$, odnosno iskustva za koja možemo pretpostaviti da su traumatska, poput alkoholizma u obitelji $(\mathrm{N}=23)$.

Sudionici u prosjeku navode $13,98(\mathrm{SD}=8,21)$ poteškoća $(\mathrm{D}=8)$, pri čemu je najmanji naznačeni broj poteškoća 1 , a najveći 46. Studentice navode značajno više poteškoća $(\mathrm{M}=14,48 ; \mathrm{SD}=8,14)$ u odnosu na $12,3(\mathrm{SD}=8,23)$ koliko navode studenti $(\mathrm{t}=2,24 ; \mathrm{P}=0,025)$, a za šestinu poteškoća utvrđena je značajna razlika po spolu (Tablica 3 ). Rodne razlike provjerene su $\chi^{2}$ testom: studenti imaju veći rezultat za alkohol, drogu i kriminal, a studentice u većoj mjeri imaju lošiju sliku o sebi, te ih više muče problemi prilagodbe i zdravstveni problemi.

Po ukupnom broju poteškoća studenti na drugoj godini $(\mathrm{M}=16,2 ; \mathrm{SD}=8,92)$ imaju značajno više poteškoća $(\mathrm{F}=6,32 ; \mathrm{P}=0,002)$ od prve $(\mathrm{M}=13,2 ; \mathrm{SD}=8,0)$

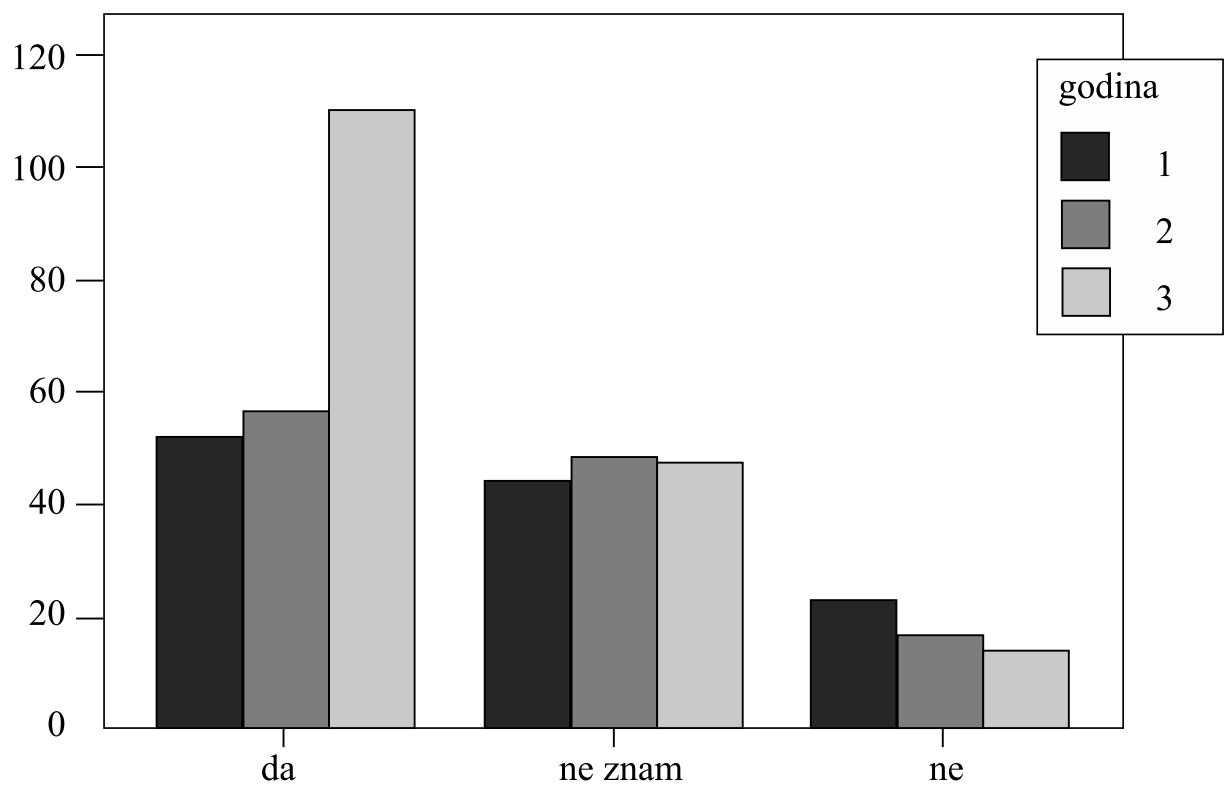

Slika 1. Učestalost odgovora o korištenju besplatne psihološke pomoći s obzirom na godinu studiranja 
i treće godine $(M=13,1 ; S D=7,54)$. Efekt interakcije spola i godine studija nije se pokazao značajnim.

Na pitanje "Kada biste bili u mogućnosti besplatno, uz potpunu diskreciju, dobiti kvalitetnu stručnu psihološku podršku i pomoć, biste li je potražili?" potvrdno je odgovorilo $51,5 \%$ studenata, $32,9 \%$ nije sigurno, a ostali ne bi potražili pomoć (13\%). Preferiraju individualno savjetovanje ( $83,7 \%$ studenata), potom sudjelovanje u radionicama $(8,5 \%)$, a samo $5,9 \%$ sudjelovalo bi i u grupnom savjetovanju. Nisu utvrđene značajne rodne razlike u potrebi za besplatnom psihološkom pomoći. Isto tako, s obzirom na to bi li potražili pomoć ili ne, nije utvrđena značajna razlika u rezultatima na subskalama odnosi s drugima i kompetencije, niti za jedan pojedinačni aspekt zadovoljstva životom. Studenti treće godine bi u značajno većoj mjeri potražili pomoć $\left(\chi^{2}=17,45 ; \mathrm{P}=0,002\right)$, a također oni koji bi potražili pomoć navode veći broj teškoća $(\mathrm{M}=14,6 ; \mathrm{SD}=8,33)$, u odnosu na $11,5(\mathrm{SD}=6,81)$ koliko navode oni koji ne bi potražili pomoć.

\section{RASPRAVA}

Osim akademskih teškoća, studente često prate i dodatni problemi, npr. nalaženje smještaja ili neizvjesnost oko buduće karijere, a određeni dio studenata ne snalazi se dobro u tim novim uvjetima, zahtjeve doživljavaju preteškima, što dodatno izaziva njihovu zabrinutost i povećava psihološku ranjivost. Razlozi za to mogu biti nedostatan razvoj sposobnosti i vještina, neadekvatni načini suočavanja s problemima, slaba socijalna podrška, zdravstvene poteškoće ili problemi iz predstudentskih dana. Kako bi sustav podrške bio što kvalitetnije prilagođen potrebama studenata, svakako je važno identificirati opseg i vrstu problema koji muče studente, što je bio i glavni cilj ovog rada.

\section{Zadovoljstvo različitim aspektima života}

Studenti zdravstvenih studija uglavnom su zadovoljni različitim aspektima života. Najviše su zadovoljni odnosima s članovima njihove uže obitelji i prijateljima, a ti se nalazi razlikuju od onih Nekić i sur. (2008) na zadarskim studentima, koji su najzadovoljniji svojim intelektualnim sposobnostima i socijalnim vještinama. Ljubavna veza je među stavkama kojima su studenti najmanje zadovoljni, kako u našem, tako i u već spomenutom istraživanju Nekić i sur. (2008).

Studentice su uglavnom manje zadovoljne nego studenti. Kararić i sur. (2012) za razliku od našeg istraživanja, nisu utvrdili značajnu razliku u zadovoljstvu životom između studenata i studentica sestrinstva, što može biti dijelom objašnjeno drukčijim konceptom primijenjene skale od naše: njihova pitanja odnosila su se općenito na zadovoljstvo životom. Literatura i inače obiluje kontradiktornim nalazima o rodnim razlikama u zadovoljstvu životom ili dobrobiti (Ozben, 2013; Della Giusta i sur., 2011; Clench-Aas, Nes, Dalgard i Aarø, 2011). Della Giusta i suradnice 
(2011) u svom opsežnom istraživanju utvrdile su vrlo slične prosječne vrijednosti za oba spola, kao i da žene pokazuju znatno veći varijabilitet u zadovoljstvu životom, a neusklađenost nalaza različitih istraživanja autorice uglavnom pripisuju razlikama $\mathrm{u}$ uzorcima i instrumentima primijenjenim u istraživanjima.

Studenti na višim godinama zadovoljniji su svojim uspjehom u studiju, tjelesnim izgledom, vještinama učenja. Stariji studenti imaju potvrdu svojih sposobnosti učenja činjenicom da su do sada zadovoljili akademske zahtjeve, te im to daje osjećaj uspješnosti. Veća emocionalna zrelost iskazuje se i u prihvaćanju vlastitog tijela. Nalazi su u skladu s istraživanjem Kararića i sur. (2012), koji su na uzorku studenata sestrinstva utvrdili veće zadovoljstvo životom studenata druge i treće godine studija, uz interpretaciju da su oni već navikli na dodatne obaveze i promijenjen način života s više obaveza.

\section{Poteškoće studenata}

$\mathrm{Na}$ samom vrhu problema nalaze se napetost ili nervoza, nesigurnost glede buduće karijere, te neracionalno korištenje vremena za učenje i zabavu. Ta tri problema najučestalije su navedena i u istraživanju Nekić i sur. (2008) na studentima Sveučilišta u Zadru, uz strah od neuspjeha u studiju. U znatnom postotku navedeni su i financijski problemi (također visokopozicioniran problem kod Nekić i sur., 2008), promjene u navikama hranjenja, te nezadovoljstvo studijem. U istraživanju Bajsa i sur. (2002), najizrazitiji studentski problemi također su briga za budućnost $i$ problemi vezani uz školovanje, što govori i o vremenskoj i o prostornoj rasprostranjenosti tih studentskih briga.

Studenti u ovom istraživanju u prosjeku navode 14 poteškoća, što je manje od 18,7 poteškoća studenata iz reprezentativnog uzorka Sveučilišta u Zagrebu (JokićBegić i sur., 2009). Dobivena razlika se možda može objasniti specifičnim odabirom vrste studija. Cvitan i sur. (2011) također su utvrdili manji broj poteškoća kod studenata stručnih studija u odnosu na sveučilišne. Većina istraživanja provodi se na sveučilišnim studentima, dok studenti na veleučilištima i visokim školama u Hrvatskoj često nisu u fokusu istraživanja iako čine 21\% studentske populacije (Doolan, Dolenec i Domazet, 2012).

Nalaz da studentice doživljavaju znatno više psiholoških poteškoća nego studenti ne iznenađuje jer studentice u brojnim istraživanjima iskazuju slabiju emocionalnu prilagodbu na studij (Baker, 2003), za što se smatra odgovornim manjak njihova samopouzdanja i asertivnosti. Bezinović i sur. (1998) dobili su značajne rodne razlike na Riječkom sveučilištu za probleme u međuljudskim odnosima, vlastitom izgledu i osjećaju neprimjerenosti, što se dobrim dijelom poklapa s našim rezultatima (nezadovoljstvo sobom, tjelesnom težinom i izgledom, omalovažavanje sebe, nedostatak svijesti o vlastitim sposobnostima, strah od neuspjeha u studiju, poteškoće u prilagodbi mjestu studiranja i okolini, te sumnja u pravilan izbor studija). Žene su sklonije anksioznosti i depresiji (Davison i Neale, 1999; Hollander i 
Simeon, 2006, Zascavage i sur., 2012), pa zbog svega navedenog ovaj je nalaz bio i očekivan. Kararić i sur. (2012) također su utvrdili izraženiju psihološku dobrobit studenata sestrinstva u odnosu na studentice, dok Bajs i sur. (2002) navode da kod adolescentica postoji jasna sklonost davanju viših procjena izraženosti problema. Nasuprot tome, Taslak i Tolanov (2011) utvrdile su da studentice Filozofskog fakulteta u Zagrebu pokazuju bolju prilagodbu u odnosu na studente, kao i Živčić-Bećirević i suradnice (2007), koje su na Riječkom sveučilištu utvrdile da studentice imaju bolju akademsku i socijalnu prilagodbu, ali slabiju emocionalnu. Žene su sklonije o svojim problemima otvoreno razgovarati, češće i traže psihološku pomoć, pa tako udio studentica u ukupnom broju prijavljenih u studentsko savjetovalište Riječkog sveučilišta iznosi više od $80 \%$ (Živčić-Bećirević i sur., 2007).

Jedino istraživanje na veleučilišnim studentima u Hrvatskoj koje smo, za sada, uspjeli naći pokazuje da su studenti jednog privatnog visokog učilišta dobro akademski i socijalno prilagođeni studiju (Vrhovski, Fratrić Kunac i Ražić, 2012). No, naši su rezultati teško usporedivi s njihovima zbog korištenja različitih mjernih instrumenata.

Čini se da su u našem uzorku u najlošijoj situaciji studenti druge godine studija jer imaju značajno više poteškoća od prve i treće godine. Taslak i Tolanov (2011) dobili su razliku u boljoj emocionalnoj prilagođenosti studenata tek na posljednjoj godini diplomskog studija. Mahmoud i sur. (2012) su u svom istraživanju dobili višu razinu anksioznosti i stresa kod studenata druge godine u odnosu na brucoše i studente završnih godina, što je u skladu s rezultatima našeg istraživanja. Takav nalaz objašnjavaju postojećim strategijama i programima u okviru sveučilišta koji su uglavnom usmjereni na studente u nekoj prijelaznoj obrazovnoj fazi kao što je početak odnosno završetak studiranja. To možda može objasniti i rezultate ovog istraživanja jer iako ne postoji sustavan program i strategija pružanja pomoći, nastavnici u okviru svojih kolegija, kao i voditelji studija su možda više usmjereni na pružanje praktičnih informacija i podrške studentima koji su tek počeli studirati, kao i onima koje treba pripremiti za završetak studija i traženje zaposlenja.

\section{Psihološka pomoć i radionice}

Više od polovine studenata navodi da bi bili spremni potražiti besplatnu psihološku pomoć (pri čemu preferiraju individualno savjetovanje), dok trećina studenata nema jasan stav oko toga. Slične rezultate dobile su Nekić i sur. (2008) za studente Zadarskog sveučilišta: nešto manje od polovine njihovih studenata potražilo bi pomoć, prvenstveno individualno savjetovanje. Treba ipak imati na umu da postoji velika razlika u odgovorima studenata koje daju u istraživanjima, od prevalencije njihova stvarnog javljanja u savjetovališta. Iskustvo nam govori da se u dvije godine rada savjetovališta za studente zdravstvenih studija prijavilo tek 30 -ak studenata. Očito je puno lakše reći nego zaista potražiti pomoć u savjetovalištu, a, s druge strane, možemo pretpostaviti da s većinom problema studenti mogu sami izaći na 
kraj. Lowinger (2012) navodi da manje od polovice studenata koji imaju potrebu za podrškom po pitanju mentalnog zdravlja, istu i dobije. Bojanić i suradnici (2016) ističu kako 32,8\% studenata izvještava o klinički značajnom stupnju psihičke uznemirenosti, dok je samo $23,6 \%$ od onih rizičnih potražilo stručnu pomoć. Kao jednu od glavnih barijera traženju stručne pomoći studenti najčešće navode kako nisu sigurni u ozbiljnost vlastitih problema, iz čega autori zaključuju da studentsku populaciju treba posebno educirati o simptomima psihičkih poremećaja, te o razlici između normalne reakcije na stres i one koja zahtijeva stručnu pomoć.

U našem istraživanju studentice i studenti ne razlikuju se značajno po spremnosti za traženje psihološke pomoći, što je različito od drugih istraživanja koja su utvrdila veću spremnost studentica (Sremec Nebić, Živčić-Bećirević i Jakovčić, 2008; Lowinger, 2012). Jakovčić i Živčić-Bećirević (2009) također su utvrdile navedenu razliku po spolu, uz dodatni nalaz da studenticama manje smeta stigma kojoj bi zbog toga mogle biti izložene. S povećanjem dobi povećava se spremnost za traženjem psihološke pomoći. Možda su zbog povećanja dobi svjesniji važnosti takve pomoći, a ujedno manje opterećeni mišljenjem drugih o vlastitim postupcima. U skladu s očekivanjima, studenti koji imaju značajno više problema, skloniji su potražiti psihološku pomoć.

Provedeno istraživanje ima određenih ograničenja, a jedno od njih je odabir instrumenta za ispitivanje studentskih problema u obliku check-liste, umjesto Ljestvice studentskih problema koja ima ponuđene odgovore po sistemu stupnjevite skale procjene (Bezinović i sur., 1998). Iako bi primjena ljestvice produljila vrijeme ispunjavanja upitnika, njome bismo dobili i intenzitet pojavljivanja pojedinih problema, što bi dodatno poboljšalo osjetljivost mjerenja i mogućnost prepoznavanja rizičnih studenata. Sporadično pojavljivanje većine problema događa se gotovo svima, ali pritom ne mora ugroziti funkcioniranje osobe. Tek s većom učestalošću ili intenzitetom problema, moguće su i posljedične poteškoće u funkcioniranju pojedinca.

Prigodan uzorak još je jedan od nedostataka ovog istraživanja, pa time i rezultati prvenstveno daju uvid $\mathrm{u}$ poteškoće $\mathrm{s}$ kojima se susreću studenti na zdravstvenim studijima, te upućuju na potrebu za pružanjem psihološke pomoći kroz rad savjetovališta. Kako se radi o budućim zdravstvenim djelatnicima, od velike je važnosti da posjeduju vještinu uspješnog suočavanja s poteškoćama i psihološki optimalno funkcioniraju, kako se njihovi životni problemi ne bi odrazili na njihov profesionalni rad. Vjerujemo da ovo istraživanje dodatno pridonosi rasvjetljavanju poteškoća (ili barem potvrđuje postojeće nalaze), s kojima se i inače studentska populacija susreće.

\section{LITERATURA}

Bajs, M., Bugan, A., Bumber, Ž, Burger, T., Čavar, I., Severinac, A. i Štefok, I. (2002). Potrebe i problemi mladih u Hrvatskoj. Diskrepancija, 5-6, 31-42. 
Baker, S.R. (2003). A prospective longitudinal investigation of social problem-solving appraisals on adjustment to university, stress, health, and academic motivation and performance. Personality and Individual Differences, 35(3), 569-591.

Berk, L.E. (2008). Psihologija cjeloživotnog razvoja. Jastrebarsko: Naklada Slap.

Bezinović, P., Pokrajac-Bulian, A., Smojver-Ažić, S. i Živčić-Bećirević, I. (1998). Struktura i zastupljenost dominantnih psiholoških problema u studentskoj populaciji. Društvena istraživanja, 36-37, 525-541.

Bojanić, L., Gorski, I. i Razum, J. (2016). Zašto studenti ne traže pomoć? Barijere u traženju stručne pomoći kod studenata s psihičkim smetnjama. Socijalna psihijatrija, 44, 330-342.

Clench-Aas, J., Nes, R.B., Dalgard, O.S. i Aarø, L.E. (2011). Dimensionality and measurement invariance in the Satisfaction with life scale in Norway. Quality of life research, 20, 1307-1317.

Cvitan, M., Doolan, K., Farnell, T. i Matković, T. (2011). Socijalna i ekonomska slika studentskog života u Hrvatskoj: nacionalno izvješće istraživanja EUROSTUDENT za Hrvatsku. Zagreb: Institut za razvoj obrazovanja.

Davison, G.C. i Neale, J.M. (1999). Psihologija abnormalnog doživljavanja i ponašanja. Jastrebarsko: Naklada Slap.

Della Giusta, M., Jewell, S.L. i Kambhampati, U.S. (2011). Gender and life satisfaction in the UK. Feminist Economics, 17, 1-34.

Devi, R, Devaki, P.R., Madhavan, M. i Saikumar, P. (2013). The Effect of Counselling on the Academic Performance of College Students. Journal of Clinical and Diagnostic Research, 7(6). 1086-1088.

Doolan, K., Dolenec, D. i Domazet, M. (2012). Hrvatski sustav financiranja visokog obrazovanja u europskom kontekstu: komparativna studija. Zagreb: Institut za razvoj obrazovanja.

Douce, L.A. i Keeling, R.P. (2014). A Strategic Primer on College Student Mental Health. American Council on Education. Washington.

Državni zavod za statistiku. Priopćenje. Studenti upisani na stručni i sveučilišni studij u zimskom semestru ak. g. 2016./2017. https://www.dzs.hr/Hrv_Eng/publication/2017/08-01-07_01_2017.htm, preuzeto 14.09.2017.

Francis, P.S. i Horn, A.S. (2017). Mental Health Issues and Counselling Services in US Higher Education: An Overview of Recent Research and Recommended Practices. Higher Education Policy.

Gallagher, R.P. (2014). National Survey of College Counselling Centers. The International Association of Counselling Services, Inc.

Harris, R.J. (1975). A primer of multivariate statistics. New York: Academic Press.

Hollander, E. i Simeon, D. (2006). Anksiozni poremećaji. Jastrebarsko: Naklada Slap.

Jakovčić, I. i Živčić-Bećirević, I. (2009). Stavovi studenata prema traženju psihološke pomoći. Socijalna psihijatrija, 37, 3-10.

Jakovčić, I., Živčić-Bećirević, I. i Birosavljević, G. (2015). Učinkovitost psihološkog savjetovanja studenata riječkog Sveučilišta. Psihologijske teme, 24(3), 495-516. 
Jokić-Begić, N., Lugomer-Armano, G. i Vizek Vidović, V. (2009). Vodič za savjetovatelje u području psihološkog savjetovanja studenata. Zagreb: Filozofski fakultet Sveučilišta u Zagrebu.

Kararić, D., Sindik, J., Raguž, V., Klokoč, P., Milovčević, V. i Burum, M. (2012). Odnos zadovoljstva životom i psihološke dobrobiti sa stresom i mentalnom čvrstoćom kod studenata sestrinstva. Hrvatski časopis za javno zdravstvo, 29, 35-48.

Lenz, V., Vinković, M. i Degmečić, D. (2016). Pojavnost depresije, anksioznosti i fobija u studenskoj populaciji Medicinskog i Pravnog fakulteta u Osijeku. Socijalna psihijatrija, 44, 120-129.

Lowinger, R.J. (2012). College students' perceptions of severity and willingness to seek psychological help for drug and alcohol problems. College Student Journal, 46, 829833.

Mahmoud, J.S.R., Staten, R.T., Hall, L.A. i Lennie, T.A. (2012) The Relationship among Young Adult College Students' Depression, Anxiety, Stress, Demographics, Life Satisfaction and coping Styles. Issues in Mental Health Nursing, 33, 149-156.

Nekić, M., Tucak Junaković, I., Macuka, I., Burić, I., Vulić Prtorić, A. i Ivanov, L. (2008). Problemi i poteškoće studenata Sveučilišta u Zadru: Potreba za otvaranjem studentskog savjetovališta. Knjiga sažetaka XVI. Dana psihologije u Zadru, Odjel za psihologiju Sveučilišta u Zadru, 132-132.

Ozben, S. (2013). Social skills, life satisfaction, and loneliness in Turkish university students. Social behavior and personality, 41, 203-214.

Sremec Nebić, T., Živčić-Bećirević, I. i Jakovčić, I. (2008). Psihološki problemi studenata Riječkog sveučilišta. Knjiga sažetaka XVI. Dana psihologije u Zadru, Odjel za psihologiju Sveučilišta u Zadru, 134-134.

Tabachnick, B.G. i Fidell, L.S. (2007). Using multivariate statistics. Boston: Pearson education.

Taslak, M. i Tolanov, A. (2011). Prilagodba na studij te struktura i zastupljenost psiholoških problema kod studenata Filozofskog fakulteta u Zagrebu. Knjiga sažetaka 20. Dana Ramira i Zorana Bujasa, Odjel za psihologiju Filozofskog fakulteta Sveučilišta u Zagrebu i Hrvatsko psihološko društvo, 182-182.

Vrhovski, I., Fratrić Kunac, S. i Ražić, M. (2012). Akademska i socijalna prilagodba na studij na primjeru studenata privatnog visokog učilišta. Praktični menadžment, 3, 34-40.

Wilson, S., Mason, T. i Ewing, M. (1997). Evaluating the impact of receiving universitybased counseling services on students retention. Journal of Counseling Psychology, 44(3), 316-320.

Zascavage, V., Winterman, K.G., Buot, M., Wies, J.R. i Lyzinski, N. (2012). Student-life stress in Education and Health Service majors. Higher Education Research and Development, 31(4), 599-610.

Živčić-Bećirević, I., Smojver-Ažić, S., Kukić, M. i Jasprica, S. (2007). Akademska, socijalna i emocionalna prilagodba na studij s obzirom na spol, godinu studija i promjenu mjesta boravka. Psihologijske teme, 16, 121-140. 


\title{
PRESENCE OF DIFFICULTIES AND SATISFACTION WITH DIFFERENT ASPECTS OF LIFE IN HEALTH STUDIES STUDENTS
}

\begin{abstract}
Summary
Previous studies of psychological adjustment of the student population show that it's a population in which emotional, motivational and social problems are often connected with study problems, study choice and academic failure. We were interested to know which problems health sciences' students usually meet in one of the largest studies in Croatia. We conducted a survey on 423 students, using questionnaire given to us by the Student counseling service from the Faculty of Philosophy in Zagreb. Beside examining their difficulties, we examined students' different aspects of life satisfaction, and their attitude for seeking assistance. The average age of participants was 20.9 , with predominately female students $(79 \%)$.

In case of difficulties, $51.5 \%$ of students would seek free psychological counseling, and those would predominately be third year students. Students usually indicate, on average 14 difficulties, most of which are nervousness or anxiety, uncertainty about their future career, irrational time usage, financial problems and changes in eating habits. Second year students indicate significantly more difficulties than others. Also, female students indicate a significantly higher number of difficulties, most of which are concerns about their appearance and problem solving skills.
\end{abstract}

Keywords: students, psychological difficulties, psychological help, life satisfaction 